\title{
Haematological Indices, Feed and Water Intake of Grower Rabbits (Oryctolagus cuniculus) Fed Graded Levels of Sheabutter (Vitellaria paradoxa C.F. Gaertn.) Nut Meal
}

\author{
Idahor K. O. ${ }^{1 *}$, Adua M. M. ${ }^{1}$, Osayande U. D. ${ }^{2}$, Kaye, J. ${ }^{3}$, Igoche L. E. ${ }^{3}$, Osaiyuwu O. H. ${ }^{2}$, \\ Sokunbi O. A. ${ }^{2}$ \\ ${ }^{1}$ Department of Animal Science, Nasarawa State University, Keffi, Shabu-Lafia Campus, Lafia, 950101, Nigeria \\ ${ }^{2}$ Animal Science Department, Faculty of Agriculture and Forestry, University of Ibadan, Ibadan, Nigeria \\ ${ }^{3}$ Department of Animal Production, Faculty of Agriculture, University of Jos, Nigeria
}

*Corresponding Author: Idahor K. O, Department of Animal Science, Nasarawa State University, Keffi, Shabu-Lafia Campus, Lafia, 950101, Nigeria

\begin{abstract}
Sixty grower rabbits were allotted to five treatments designated as T1: $0.0 \%$ SNM; T2: 2.0\% SNM; T3: 4.0\% SNM, T4: 6.0\% SNM and T5: 8.0\% SNM. Data were collected on haematological indices, feed and water intake. Results showed that the feed intake value was $2.7 \mathrm{~kg} / \mathrm{wk}(T 5), 2.63 \mathrm{~kg} / \mathrm{wk}(T 1), 2.61 \mathrm{~kg} / \mathrm{wk}(T 2)$, $2.8 \mathrm{~kg} / \mathrm{wk}$ (T4) and $2.97 \mathrm{~kg} / \mathrm{wk}$ (T2) in weeks 1 to 5 , but increased from $3.03 \mathrm{~kg} / \mathrm{wk}$ in T5 (6 ${ }^{\text {th }}$ week) to 3.49 $\mathrm{kg} / \mathrm{wk}$ (control diets) in week 9. In week 2, water intake values ranged from $4.42 \mathrm{l} / \mathrm{wk}$ (T1) to $4.6 \mathrm{l} / \mathrm{wk}$ (T3) and there was an increase from a range of 4.7 to $4.82 \mathrm{l} / \mathrm{wk}$ in week 3 to as high as $5.26 \mathrm{l} / \mathrm{wk}$ in week 9 (T4). Haemoglobin value ranged from $7.0 \mathrm{~g} / \mathrm{dl}$ (T1) to $11.9 \mathrm{~g} / \mathrm{dl}$ (T5), packed cell volume (27.7 to 40.0\%), red blood cells $\left(2.17\right.$ to $\left.3.73 \times 10^{12} / l\right)$ and white blood cells were highest $\left(6.48 \times 10^{9} / l\right)$ in T5. The haematological indices evaluated were within the normal range of values reported thus, sheabutter nut meal maybe utilized in rabbit nutrition up to $8.0 \%$, probably with mild or no detrimental effects.
\end{abstract}

Keywords: Haematological indices, rabbit production, sheabutter, unconventional feedstuffs

\section{INTRODUCTION}

Domestication of animals started a long time ago when human civilization resulted in deliberate rearing of animal species where their behaviour, feeding and reproductive cycle were modified to suit human purposes. The role of livestock in human development includes provision of food for physical and intellectual growth as well as source of income for socio-economic advancement. According to [1], livestock production has a potential to substantially improve human living, income generation and poverty alleviation. These in turns, will in no small measure culminate in robust gross domestic product of the nation and better social economic status of the citizenry. It was stated [2] that livestock provided about $36.5 \%$ of the total protein intake by Nigerians and [3] reported that animal proteins were superior to plant proteins.

Livestock species include ruminants, poultry breeds and rabbits. Among these, rabbits are believed to be the most prolific, cost saving and economical due to their short generation interval, high litter size and require little start-pack-capital. More essentially, rabbit meat and meat products are relished by many all over the world. However, quantitative and qualitative feedstuffs availability has been the bane of rabbit production hence, the search for unconventional feed resources. Utilization of Green bean, Cantaloupe, Squash vines and Artichoke leaves [4] as well as Rice straw, Sunflower hulls, Almond husk, Cowpea and Peanut haulms [5] in rabbit diets have been reported. Likewise, the feeding of rabbits with Jack and Lima beans, Rapeseed, Cotton and Rubber seed meal [6] yet little is known about the use of sheabutter nut meal as rabbit feedstuff.

Sheabutter (Vitellaria paradoxa C.F. Gaertn.), is a deciduous small- to medium-size tree up to $15-25$ $m$ tall [7]. The fleshy fruit was reported to be a source of energy, the seeds yielded about $45 \%$ edible lardlike fat (shea butter) often used for food and cosmetics $[8,9]$. It was reported that the seeds byproducts after butter extraction known as sheabutter nut cake or meal could be utilized as feedstuff in 
livestock production. However, antinutritional factors like phenolics, tannins, saponins and alkaloids have been reported in sheabutter tree and its products [10, 11, 12, 13]. Meanwhile, [13] reported that ruminants can tolerate more sheabutter nut meal than monogastrics, but inclusion rates higher than $30 \%$ was observed to affect digestibility of other feedstuffs in the ration. It was reported [14] that boiled sheabutter nut cake was used in pigs up to $20 \%$ but higher inclusion level rate was poisonous. Lower performance, decreased red blood cells concentration, haemoglobin, haematocrit and serum cholesterol were reported in boiler thus, maximum inclusion level of $2.5 \%$ was recommended $[11,15$, $16]$.

Although, it was speculated [17] that shea nut cake could be utilized in diets of lactating buffaloes, growing buffalo calves, sheep and rabbits, the safe inclusion level was not given. Similarly, [18] fed sheanut meal to rabbits, but did not consider feed and water intake yet, recommended as high as $25 \%$ inclusion level even when mortality and effects on performance were recorded. Also, it was stated that sheanut meal was low in protein content, a potential toxicity thus, it was recommended to be used as non-nutritive bulk in diets [13]. Hence, this study was aimed at investigating the effects of graded levels of sheabutter nut meal on feed and water intake as well as haematological indices of grower rabbits.

\section{MATERIALS AND METHODS}

\subsection{Geographical Description of the Experimental Site}

The study was conducted at the Nasarawa State University Teaching and Research Farm, Shabu-Lafia Campus, Lafia, situated in the north central region of Nigeria. Lafia is located on latitude $08^{\circ} 35^{\prime} \mathrm{N}$, longitude $08^{\circ} 34^{\prime} \mathrm{E}$, altitude of $181 \mathrm{~m}$ above sea level with temperature ranging from 32 to $35^{\circ} \mathrm{C}$, relative humidity between 58 and 63\%, average day light of 9 to 12 hours and approximately 1,400 $\mathrm{mm}$ rainfall per year [19]. The vegetation consists of different species of trees, shrubs, leguminous browse plants and grasses with fairly undulated terrain.

\subsection{Chemical Analysis of Sheabutter Nut Meal}

Sheabutter nut meal was gathered from local milling centres in Kwandere, Nasarawa State, where sheabutter nut oil was extracted. Aliquots from each centre were taken, pooled and mixed properly. Samples were taken from the mixed aliquots for chemical composition determination using the procedures of [20] and the analysis is presented in Table 1.

Table1. Chemical composition of sheabutter nut meal

\begin{tabular}{|l|l|}
\hline Nutrients & Compositions \\
\hline Crude protein (\%) & 1.2 \\
\hline Crude fibre (\%) & 5.2 \\
\hline Ether extract (\%) & 45.0 \\
\hline Ash (\%) & 15.0 \\
\hline Moisture (\%) & 25.0 \\
\hline Nitrogen free extract (\%) & 8.5 \\
\hline Gross energy (kcal/kg) & $3,995.3$ \\
\hline
\end{tabular}

\subsection{Experimental Diets Formulation}

The soya bean meal and premix were obtained from Jos, Plateau State while, other feedstuffs were sourced from Shabu, Nasarawa State. The feedstuffs were used in formulating the experimental diets presented in Table 2 based on recommendations for rabbits [21]. The nutritional value of the experimental diets was calculated using feedstuff table [22].

Table2. Gross composition of the experimental diets

\begin{tabular}{|l|l|l|l|l|l|}
\hline \multirow{2}{*}{ Feedstuffs $(\%)$} & \multicolumn{5}{|c|}{ Treatments } \\
\cline { 2 - 6 } & T1 & T2 & T3 & T4 & T5 \\
\hline Maize offal & 35.0 & 34.5 & 34.0 & 33.5 & 33.0 \\
\hline Rice offal & 27.0 & 26.5 & 26.0 & 25.5 & 25.0 \\
\hline Wheat offal & 25.0 & 24.5 & 24.0 & 23.5 & 23.0 \\
\hline Soybean meal & 10.0 & 9.5 & 9.0 & 8.5 & 8.0 \\
\hline Sheabutter nut meal & 0.0 & 2.0 & 4.0 & 6.0 & 8.0 \\
\hline
\end{tabular}


Haematological Indices, Feed and Water Intake of Grower Rabbits (Oryctolagus cuniculus) Fed Graded Levels of Sheabutter (Vitellaria paradoxa C.F. Gaertn.) Nut Meal

\begin{tabular}{|l|l|l|l|l|l|}
\hline Fish meal & 2.0 & 2.0 & 2.0 & 2.0 & 2.0 \\
\hline Premix & 2.0 & 2.0 & 2.0 & 2.0 & 2.0 \\
\hline Salt & 0.25 & 0.25 & 0.25 & 0.25 & 0.25 \\
\hline Bone meal & 0.25 & 0.25 & 0.25 & 0.25 & 0.25 \\
\hline Lysine & 0.15 & 0.15 & 0.15 & 0.15 & 0.15 \\
\hline Methionine & 0.15 & 0.15 & 0.15 & 0.15 & 0.15 \\
\hline Total & $\mathbf{1 0 0 . 0}$ & $\mathbf{1 0 0 . 0}$ & $\mathbf{1 0 0 . 0}$ & $\mathbf{1 0 0 . 0}$ & $\mathbf{1 0 0 . 0}$ \\
\hline Calculated nutrients & 16.5 & 16.1 & 15.8 & 15.4 & 15.0 \\
\hline Crude protein & 11.4 & 11.4 & 11.2 & 11.7 & 11.0 \\
\hline Crude fibre & $2,869.3$ & $2,854.9$ & $2,938.7$ & $2,908.9$ & 2.992 .4 \\
\hline Metabolizable energy
\end{tabular}

Premix composition/100kg diet: Vitamin A = 15,000 IU, Vitamin D3 = 300,000 IU, Vitamin K= 2.5mg, Vitamin $B 1=200 m g$,

Vitamin B2 = 600mg, Niacin = 40mg, Vitamin B12 = 2mg, Pantothenic acid $=10.0 \mathrm{mg}$, Folic acid $=100 \mathrm{mg}$, biotin $=8 m g$, Antioxidant $=12.5 \mathrm{~g}, \mathrm{Cl}=50 \mathrm{~g}, \mathrm{Mn}=96 \mathrm{~g}, \mathrm{Zn}=6 \mathrm{~g}, \mathrm{Fe}=24 \mathrm{~g}, \mathrm{Cu}=0.6 \mathrm{~g}, \mathrm{I}=0.14 \mathrm{~g}, \mathrm{Se}=24 \mathrm{mg}$, Co $=2.4 m g$.

\subsection{Expe rimental Design and Animal Welfare}

A total of 60 mixed breed grower rabbits at 7 weeks old, weighing between 0.97 and $1.2 \mathrm{~kg}$ were bought from National Veterinary Research Institute, Plateau State, Nigeria. They were randomly distributed into five treatments (T1: 0.0\% SNM; T2: 2.0\% SNM; T3: 4.0\% SNM, T4: 6.0\% SNM; T5: $8.0 \%$ SNM). Each of the treatments had a total of twelve rabbits (1 buck: 1 doe ratio) that were paired based on sex in hutches measuring $64 \mathrm{~cm}$ length x $62 \mathrm{~cm}$ width $\times 48 \mathrm{~cm}$ height. The formulated diets and clean drinking water were offered to the experimental animals ad libitum. The hutches, pens, water troughs and feed troughs were thoroughly cleaned, washed as well as disinfected at regular interval and the environment was often cleared to maintain good hygiene. Lighting system was provided in the pens in order to give illumination, warmth and enhance feeding at night throughout the nine weeks experimental period. In the course of two weeks adaptation period, anti-stress, antibiotics and anthelmintic were administered according to the manufacturers' instructions. This experiment was carried out purely as an observational work so, ethical permission was not considered necessary. More importantly, Animal Care and Use of Experimental Animals clearance was not obtained, because these laws do not exist in my Institution (Nasarawa State University, Keffi, ShabuLafia Campus) at the moment.

\subsection{Data Collection and Statistical Analys is}

The feed offered and the remnants were weighed, the differences in values were considered as the feed intake and the values were recorded weekly. The volume of water offered and the leftover were measured in $1000 \mathrm{ml}$ volumetric flask and the differences in values were recorded as water intake on weekly basis. At the end of the feeding trial, blood samples were collected from six rabbits (1buck: 1doe) per treatment through cardiac acupuncture by a veterinary expert. The blood samples were collected in bottles containing ethylene diamine tetra-acetic acid for haemoglobin, packed cell volume, platelet, red and white blood cells determination [23]. Data collected were analysed according to analysis of variance of [24] statistical package and the mean values were separated where applicable, using least significant difference of the same software.

\section{RESULTS}

Table3. Feed intake of grower rabbits fed graded levels of sheabutter nut meal $(\mathrm{kg} / \mathrm{wk})$

\begin{tabular}{|l|l|l|l|l|l|l|l|l|}
\hline \multirow{3}{*}{ Week } & \multicolumn{3}{|c|}{ Level of sheabutter nut meal inclusion (\%) } & \multicolumn{3}{c|}{ Statistics } \\
\cline { 2 - 10 } & $\mathbf{0 . 0}$ & $\mathbf{2 . 0}$ & $\mathbf{4 . 0}$ & $\mathbf{6 . 0}$ & $\mathbf{8 . 0}$ & Mean & MSE & P-value \\
\hline 1 & $2.15^{\mathrm{c}}$ & $2.42^{\mathrm{b}}$ & $2.38^{\mathrm{b}}$ & $2.70^{\mathrm{a}}$ & $2.49^{\mathrm{b}}$ & 2.43 & 0.089 & 0.01 \\
\hline 2 & 2.63 & 2.54 & 2.43 & 2.42 & 2.45 & 2.49 & 0.033 & 0.65 \\
\hline 3 & 2.54 & 2.61 & 2.59 & 2.57 & 2.58 & 2.57 & 0.002 & 0.28 \\
\hline 4 & 2.75 & 2.81 & 2.79 & 2.80 & 2.76 & 2.78 & 0.001 & 0.32 \\
\hline 5 & 2.92 & 2.97 & 2.96 & 2.93 & 2.94 & 2.94 & 0.001 & 0.46 \\
\hline 6 & 3.06 & 3.06 & 3.09 & 3.04 & 3.03 & 3.06 & 0.001 & 0.55 \\
\hline 7 & 3.07 & 3.08 & 3.07 & 3.06 & 3.05 & 3.07 & 0.002 & 0.63 \\
\hline
\end{tabular}


Haematological Indices, Feed and Water Intake of Grower Rabbits (Oryctolagus cuniculus) Fed Graded Levels of Sheabutter (Vitellaria paradoxa C.F. Gaertn.) Nut Meal

\begin{tabular}{|l|l|l|l|l|l|l|l|l|}
\hline 8 & 3.35 & 3.23 & 3.23 & 3.29 & 3.28 & 3.28 & 0.005 & 0.71 \\
\hline 9 & 3.49 & 3.37 & 3.37 & 3.41 & 3.41 & 3.40 & 0.015 & 0.62 \\
\hline No. of animals & 12 & 12 & 12 & 12 & 12 & - & - & - \\
\hline
\end{tabular}

$a, b, c$ : Means along the same row with different superscripts differ significantly at P<0.05; MSE: Mean standard error; T1: 0.0\% SNM; T2: 2.0\% SNM; T3: 4.0\% SNM; T4: 6.0\% SNM; T5: 8.0\% SNM; SNM: Shea nut meal; P-value: probability level.

Table 3 shows the weekly feed intake of rabbits fed graded levels of sheabutter nut meal. There were no statistical differences $(\mathrm{P}>0.05)$ in all the mean values among the treatments. Meanwhile, feed intake values were as high as $2.7 \mathrm{~kg} / \mathrm{wk}$ (T4), $2.63 \mathrm{~kg} / \mathrm{wk}$ (T1), $2.61 \mathrm{~kg} / \mathrm{wk}$ (T2), $2.81 \mathrm{~kg} / \mathrm{wk}$ (T4) and $2.97 \mathrm{~kg} / \mathrm{wk}$ (T2) in weeks 1 to 5 respectively. It was observed that feed intake increased from a range of $3.03 \mathrm{~kg} / \mathrm{wk}$ in T5 at the $6^{\text {th }}$ week to $3.49 \mathrm{~kg} / \mathrm{wk}$ in control at the $9^{\text {th }}$ week.

Weekly water intake of rabbits fed graded levels of sheabutter nut meal is provided in Table 4. There were no statistical differences $(\mathrm{P}>0.05)$ in the mean values across the treatments. Except in week 1 , where the mean values that were similar in treatments 2,3 and 4 differed significantly $(\mathrm{P}<0.05)$ from those in $\mathrm{T} 1$ but both treatments values did not vary statistically $(\mathrm{P}>0.05)$ from those of $\mathrm{T} 5$. At the $2^{\text {nd }}$ week of the study, water intake values ranged from $4.42 \mathbf{l} / \mathbf{w k}$ (T1) to $4.61 \mathbf{l} / \mathbf{w k}$ (T3) and there was an increase from a range of $4.7-4.82 \mathrm{l} / \mathbf{w k}$ in week 3 to as high as $5.26 \mathrm{l} / \mathbf{w k}$ in T4 at the $9^{\text {th }}$ week.

Table4. Influence of diets containing graded levels of sheabutter nut meal on water intake in grower rabbits $(l / w k)$

\begin{tabular}{|l|l|l|l|l|l|l|l|l|}
\hline \multirow{2}{*}{ Week } & \multicolumn{4}{|c|}{ Level of sheabutter nut meal inclusion (\%) } & \multicolumn{3}{c|}{ Statistics } \\
\cline { 2 - 10 } & $\mathbf{0 . 0}$ & $\mathbf{2 . 0}$ & $\mathbf{4 . 0}$ & $\mathbf{6 . 0}$ & $\mathbf{8 . 0}$ & Mean & MSE & P-value \\
\hline 1 & $4.43^{\mathrm{b}}$ & $4.79^{\mathrm{a}}$ & $4.75^{\mathrm{a}}$ & $4.76^{\mathrm{a}}$ & $4.68^{\mathrm{ab}}$ & 4.68 & 0.013 & 0.00 \\
\hline 2 & 4.42 & 4.54 & 4.61 & 4.58 & 4.55 & 4.54 & 0.020 & 0.22 \\
\hline 3 & 4.75 & 4.70 & 4.69 & 4.76 & 4.82 & 4.74 & 0.027 & 0.71 \\
\hline 4 & 4.83 & 4.86 & 4.85 & 4.80 & 4.85 & 4.84 & 0.021 & 0.80 \\
\hline 5 & 4.89 & 5.02 & 4.94 & 4.90 & 5.00 & 4.95 & 0.000 & 0.38 \\
\hline 6 & 5.01 & 5.02 & 5.00 & 5.00 & 5.00 & 5.01 & 0.000 & 0.23 \\
\hline 7 & 5.10 & 5.10 & 4.84 & 5.08 & 4.98 & 5.02 & 0.080 & 0.27 \\
\hline 8 & 5.04 & 4.28 & 5.12 & 5.05 & 5.06 & 4.91 & 0.090 & 0.47 \\
\hline 9 & 5.21 & 5.16 & 5.22 & 5.26 & 5.23 & 5.22 & 0.008 & 0.32 \\
\hline No. of animals & 12 & 12 & 12 & 12 & 12 & - & - & - \\
\hline
\end{tabular}

$a, b$ : Means along the same row with different superscripts differ significantly at $P<0.05 ;$ MSE: Me an standard error; T1: 0.0\% SNM; T2: 2.0\% SNM; T3: 4.0\% SNM; T4: 6.0\% SNM; T5: 8.0\% SNM; SNM: Sheabutter nut meal; P-value: probability level.

Presented in Table 5 are the haematological indices of grower rabbits fed graded levels of sheabutter nut meal. There were significant differences $(\mathrm{P}<0.05)$ in all the parameters measured except, in white blood cells whose values ranged from $5.28 \times 10^{9} / 1$ in $\mathrm{T} 1$ to $6.48 \times 10^{9} / 1$ in T5. Haemoglobin value was statistically superior $(\mathrm{P}<0.05)$ in $\mathrm{T} 5(11.9 \mathrm{~g} / \mathrm{dl})$ compared to $10.1 \mathrm{~g} / \mathrm{dl}, 10.5 \mathrm{~g} / \mathrm{dl}$ and $10.9 \mathrm{~g} / \mathrm{dl}$ recorded in treatments 5,3 and 2 respectively. These values were however similar but differed significantly $(\mathrm{P}<0.05)$ from $7.0 \mathrm{~g} / \mathrm{dl}$ recorded in the control. The packed cell volume was highest $(40.0 \%$ ) in T5 followed by $33.0 \%$ (T3), 32.7\% (T2), 29.7\% (T4) and 27.7\% (T1) respectively.

Table5. Haematological indices of grower rabbits fed graded levels of sheabutter nut meal

\begin{tabular}{|c|c|c|c|c|c|c|c|c|}
\hline \multirow[b]{2}{*}{ Parameters } & \multicolumn{5}{|c|}{ Level of sheabutter nut meal inclusion (\%) } & \multicolumn{3}{|c|}{ Statistics } \\
\hline & $\mathbf{0 . 0}$ & 2.0 & 4.0 & 6.0 & 8.0 & Mean & MSE & P-value \\
\hline $\begin{array}{l}\text { Number of animals } \\
\text { Haemoglobin }(\mathrm{g} / \mathrm{dl})\end{array}$ & $\begin{array}{l}6 \\
7.0^{c}\end{array}$ & $\begin{array}{l}6 \\
10.9^{b}\end{array}$ & $\begin{array}{l}6 \\
10.5^{\mathrm{b}}\end{array}$ & $\begin{array}{l}6 \\
10.1^{\mathrm{b}}\end{array}$ & $\begin{array}{l}6 \\
11.9^{\mathrm{a}}\end{array}$ & $\begin{array}{l}- \\
10.1\end{array}$ & $-\overline{0}$ & $\overline{-}-000$ \\
\hline Packed cell volume $(\%)$ & $27.7^{\mathrm{d}}$ & $32.7^{\mathrm{b}}$ & $33.0^{\mathrm{b}}$ & $29.7^{\mathrm{c}}$ & $40.0^{\mathrm{a}}$ & 32.6 & 3.36 & 0.000 \\
\hline Platelets $\left(\mathrm{x} 10^{9} / 1\right)$ & $332.5^{\mathrm{b}}$ & $439.3^{\mathrm{a}}$ & $296.5^{\mathrm{c}}$ & $176.7^{\mathrm{d}}$ & $176.3^{\mathrm{d}}$ & 284.3 & 12.9 & 0.002 \\
\hline Red blood cells $\left(\mathrm{x} 10^{12} / 1\right)$ & $2.17^{\mathrm{d}}$ & $2.91^{\mathrm{b}}$ & $2.88^{\mathrm{b}}$ & $2.48^{\mathrm{c}}$ & $3.73^{\mathrm{a}}$ & 2.83 & 0.012 & 0.000 \\
\hline $\begin{array}{l}\text { White blood cells }\left(\mathrm{x} 10^{9} / \mathrm{l}\right) \\
\text { Mortality }(\%)\end{array}$ & $\begin{array}{l}5.28 \\
0.0\end{array}$ & $\begin{array}{l}5.65 \\
0.0\end{array}$ & $\begin{array}{l}6.13 \\
0.0\end{array}$ & $\begin{array}{l}5.45 \\
0.0\end{array}$ & $\begin{array}{l}6.48 \\
0.0\end{array}$ & $\begin{array}{l}5.80 \\
0.0\end{array}$ & $\begin{array}{l}1.75 \\
0.0\end{array}$ & $\begin{array}{l}0.507 \\
0.0\end{array}$ \\
\hline
\end{tabular}

$a, b, c, d$ : Means along the same row with different superscripts differ significantly at $P<0.05 ;$ MSE: Mean standard error; T1: 0.0\% SNM; T2: 2.0\% SNM; T3: 4.0\% SNM; T4: 6.0\% SNM; T5: 8.0\% SNM; SNM: Sheabutter nut meal; $P$-value: probability level. 
The platelets value was similar in treatments $4\left(176.7 \times 10^{9} / 1\right)$ and $5\left(176.3 \times 10^{9} / 1\right)$ but both values were statistically lower $(\mathrm{P}<0.05)$ than $296.5 \times 10^{9} / 1,332.5 \times 10^{9} / 1$ and $439.3 \times 10^{9} / 1$ recorded in T3, T1 and T2 in that arrangement. While the red blood cells values did not differ in T2 $\left(2.91 \times 10^{12} / \mathrm{l}\right)$ and $\mathrm{T} 3\left(2.88 \times 10^{12} / \mathrm{l}\right)$, the values were however significantly higher $(\mathrm{P}<0.05)$ than $2.48 \times 10^{12} / 1$ and $2.17 \mathrm{x}$ $10^{12} / 1$ recorded in $\mathrm{T} 4$ and control respectively but were lower than $3.73 \times 10^{12} / 1$ observed in $\mathrm{T} 5$. There was no mortality among the experimental animals throughout the study period.

\section{Dis CUSSION}

The results revealed that feed intake did not follow a particular pattern and did not differ among the treated rabbits even at every stage of the growth phases. It was observed that the rate of feed intake increased with age suggesting that the rabbits were still growing. This trend followed the report of [25] who observed increased feed intake concomitantly with increase in age of rabbits. Also, it was similar to the findings of [26] when maize was replaced with cassava peel in rabbit diets and [27] in rabbit feed restriction trial. More so, the finding was comparable with the report of [28] that fed diets containing Moringa oleifera and Leucaena leucocephala and recorded no effects on growth performance in rabbits. Although, there was somewhat distortion of feed intake at the beginning of the experiment, there was seemingly uniform trend in the subsequent weeks. This observation was probably due to acclimatisation to the test diets, environment and perhaps due to feed wastages as a result of scooping attitude of rabbits. The distorted trend was probably overcome largely due to acceptance of the experimental diets, suggesting that sheabutter nut meal may not be palatable to rabbits.

The weekly feed intake pattern indicated that the rabbits were at their grow th phases even up to the $9^{\text {th }}$ week of study, when they were about 17 weeks of age. This agreed with the report of [29] that rabbits attain full maturity at about 24 weeks of age. Also, the finding agreed partially with the report of [30] who described puberty as the stage when the endocrine functions of the testicles become clearly evident. Meanwhile, the observed feed intake value was higher than about $0.59-0.91 \mathrm{~kg} / \mathrm{wk}$ reported elsewhere [26, 27]. This could be largely due to the differences in the physiological status of the rabbits used. It was however close to about $130 \mathrm{~g}$ of feed per $\mathrm{kg}$ live weight recommended for grower rabbits [3].

Therefore, sheabutter nut meal may be included in rabbit nutrition, but the antinutritional constituents which was however not determined in the present study, should be considered in order to avert the consequences. This becomes important because of the report by [31] that antinutritional factors could reduce voluntary feed intake, diminish digestibility and utilization of nutrients as well as cause metabolic disorder and toxicity in livestock. Also, water intake was initially distorted at the beginning of the experiment but was observed to normalise subsequently. Meanwhile, the level of water intake among the treated rabbits did not follow a particular pattern and were similar among the treated rabbits.

This observation contradicted the report of [27] who reported linearity in water intake pattern in rabbits. However, the level of water intake was higher than $124-250 \mathrm{ml}$ per day and seemingly contrasted decrease in water consumption observed in rabbits of similar physiological status [27]. It was however close to about $250 \mathrm{~g}$ of water per $\mathrm{kg}$ live weight recommended for grower rabbits $[1,3]$. The observed increase in the water intake at the later stage of the experiment, probably reflected that the rabbits were still growing, concurring with the report of [1] who stated that water intake increased from 200 to $250 \mathrm{~g}$ a day per $\mathrm{kg}$ of live weight. Since the rate of water intake in the study did not follow a particular trend and did not differ among the treated rabbits, it possibly indicated that sheabutter nut meal may not unduly influence the electrolytes, ionic and metabolic activities of grower rabbits.

The white blood cells values were within $5.4-9.9 \times 10^{9} / 1$, the haemoglobin value was similar to a range of $6.7-15.4 \mathrm{~g} / \mathrm{dl}$ and the platelets value was close to $75-763 \times 10^{9} / 1$ reported in normal and healthy rabbits $[32,33,34]$. In the same trend, white blood cells value was within $5.4-9.0 \times 10^{9} / 1$, packed cell volume was comparable to $28.0-45.7 \%$ and the red blood cells were however lower than $3.5-7.0 \times 10^{12} / 1$ reported elsewhere $[32,33,34]$. The observed disparity could be largely due to the breed, age, sex as well as physiological status of the rabbits involved and partly due to the climatic conditions of the experimental sites where the studies were performed. 


\section{CONCLUSIONS}

The haematological indices, feed and water intake did not follow a linear pattern among the treated animals yet haemoglobin, packed cell volume, red and white blood cells were seemingly superior in rabbits fed $8 \%$ sheabutter nut meal. More importantly, there were observed value similarities and apparent conformities with those reported in normal, healthy and physiological conditions in rabbits and there was no mortality during the study. Therefore, inclusion of sheabutter nut meal up to $8.0 \%$ in rabbit diets may not elicit deleterious physiological responses.

\section{REFERENCES}

[1] FAO., Livestock and Animal Production. http://www.fao.org/ag/.../animal-production.htm. (2014). Accessed 20 August 2014).

[2] Atinmo A. and Akinyele O., Nutritional Food Policy of Nigeria. National Institute for Policy and Strategic Studies, Jos, Nigeria. Pp. 3-10, (1993).

[3] Olomu J. M., Monogastric Animal Nutrition, Principles and Practice. 2nd ed. Jachem Publication, Benin City, Nigeria. Pp. 478, (2011).

[4] Zaza G. H., Ibrahim M. R., Ali M. et al., Nutritional evaluation of some vegetable crops by-products as unconventional feedstuffs in rabbits feeding. Egypt J Rabbit Sci. 2, 71-862009.

[5] Das S. K. and Khargharia G., Productive performance of rabbit on unconventional feedstuffs - a review. Agric. Reviews 25(2), 141-146 (2004).

[6] Kperegbeyi J. I. and Ikperite S. E., Awareness and utilization of unconventional protein feed resources in feeding monogastric animal in south-south, Nigeria. World J Agric Biol Sci. 2(1), 1-7 (2015). http://wjabs.com/

[7] Feedipedia. Sheanut (Vitellaria paradoxa C.F. Gaertn.). Feedipedia - Animal feed resources information system - INRA CIRAD AFZ and FAO @ 2012-2016. http://www.feedipedia.org/node/5/ . (2014). Accessed 13 September 2016.

[8] Akihisa T. Kojima N., Kikuchi T., et al., Anti-inflammatory and chemopreventive effects of triterpene cinnamates and acetates from shea fat. J Oleo Sci. 59(6), 273-80 (2010). DOI:10.5650/jos.59.273.

[9] NRC., Lost Crops of Africa: Volume II: Vegetables. National Research Council. ISBN 978-0-309-103336. The National Academies Press, Washington, D.C. Pp. 378 (2006).

[10] Oddoye E. O. K., Alemawor F., Agyente-Badu K., et al., Proximate analysis of shea nut kernel cake/meal samples from industry and cottage industry and some methods of removal of antinutritional factors. Intl. J. Biochem.Biotechnol. 1, 239-242 (2012).

[11] Dei H. K., Rose S. P., Mackenzie A. M. et al., Growth performance of broiler chickens fed diets containing shea nut (Vitellaria paradoxa, Gaertn.) meal fermented with Aspergillus niger. Poult Sci. 87, 1773-1778 (2008).

[12] Annongu A. A., Termeulen U., Atteh J. O., et al., Toxicological assessment of native and industrial fermented shea butter cake in nutrition of broilers. Arch Gefluegelkd. 60, 221-226 (1996).

[13] Göhl B., Les aliments du bétail sous les tropiques. FAO, Division de Production et Santé Animale, Roma, Italy, 1982.

[14] Rhule S. W. A., Performance of pigs on diets containing detoxified shea nut cake. Trop Anim Health Prod. 31, 45-53 (1999).

[15] Pousga S., Boly H., Lindberg J. E. et al., Evaluation of traditional sorghum (Sorghum bicolor) beer residue, shea nut (Vitellaria paradoxa) cake and cotton seed (Gossypium spp) cake for poultry in Burkina Faso: availability and amino acid digestibility. Int J Poult Sci. 6, 666-672 (2007).

[16] Atuahene C. C., Donkoh A., Asante F., Value of shea nut cake as a dietary ingredient for broiler chicken. CIRAD Laboratory data 1993-2008. CIRAD Anim Feed Sci Technol. 72, 133-142 (1998).

[17] Kumar M. K., Utilization of shea nut cake in livestock feeding. J Vet Sci Technol 6, 6. (2015). http://dx.doi.org/10.4172/2157-7579.C1.011. Accessed August 18 2015).

[18] Alemede I. C., Ogunbajo S. A. and Akinbiyi O. J., Effect of feeding varying levels of sheanut meal (Vitellaria paradoxa) on haematological parameters, diseases and mortality of weaner rabbits (Oryctolagus cunniculus). Agric Biol J N Am. 4(1), 78-83 (2013). DOI:10.5251/abjna.2013.4.1.78.83.

[19] NIMET. Nigeria Metrological Agencies, Synoptic Office, Lafia, Nasarawa State, Nigeria, (2011).

[20] AOAC. Official Methods of Analysis of AOAC International (OMA). AOAC International, Gaithersburg, MD, (2012). 
[21] Lang J., The nutrition of the commercial rabbit part 1: Physiology, digestibility and nutrient requirements part 2: Feeding and general aspects of nutrition. Nutr. Abstr. Rev. Series B. Livest. Feeds. 51, 197-227; 287-302 (1981).

[22] Aduku A. O., Tropical feedstuff analysis table. Department of Animal Science, Faculty of Agriculture, Ahmadu Bello University, Samaru-Zaria, Nigeria. (1993).

[23] Mitruka B. M. and Rawnsley H., Clinical biochemistry, haematology references values in normal experimental animals (1st edn.) Masson Inc., New York, USA. Pp. 106-112 (1977).

[24] GenStat. GenStat for Windows, 8th Edition General Statistics Package. (2005).

[25] FAO., The Rabbit: Husbandry, health and production (new revised version). Food and Agriculture Organization of the United Nations, Rome. FAO Animal Production and Health. Series No. 21, AGRIS: LO1 ISSN 1010-9021. (1997).

[26] Osakwe I. I. and Nwose R. N., Feed intake and nutrient digestibility of weaner rabbits fed cassava peel as replacement for maize. Anim Res Intl. 5(1), 770-773 (2008).

[27] Verdelhan S., Bourdillon A. and Morel-Saives A., Effect of a limited access to water on water consumption, feed intake and growth of fattening rabbits. In: Proc of 8th World Rabbit Congress, Puebla, Mexico. Pp. 1015-1021 (2004).

[28] Santos-Ricalde R., Gutiérrez-Ruiz E., Novelo-Ucan W., Effect of feed restriction on intake of Moringa oleifera and Leucaena leucocephala and growth performance of rabbits. Trop Anim Health Prod. 49, 1685-1688 (2017). https://doi.org/10.1007/s 11250-017-1377-6

[29] Macari M. and Machado C. R., Sexual maturity in rabbits defined by the physical and chemical characteristics of the semen. Lab Anim Sci. 12, 37-39 (1978).

[30] Donovan B. T., van der Werff and Bosch J. J., Physiology of puberty. London: Arnold, (1965).

[31] Etuk E. B., Okeudu N. J. and Udedibie A. B. I., Antinutritional Factors in Sorghum: Chemistry, Mode of Action and Effects on Livestock and Poultry. J Anim Feed Res. 2(2), 113-119 (2012).

[32] Archetti I., Tittarelli C., Cerioli M., et al., Serum chemistry and hematology values in commercial rabbits: preliminary data from industrial farms in northern Italy. In: Proc. 9th World Rabbit Congress, Verona, Italy. Pp. 1147-1152 (2008).

[33] Moore D. M., Chapter 170. In: Feldman B. F., Zinkl J. G. and Jain N.C. (Eds.). Schalm's Veterinary Hematology, $5^{\text {th }}$ ed., Blackwell Publishing Professional, Ames, Iowa, USA. Pp. 1100-1106 (2006).

[34] Bortolotti A., Castelli D., Bonati M. et al., Serum Chemistry Values of Adults, Pregnant and Newborn New Zealand Rabbits (Oryctolagus cuniculus). Lab Anim Sci. 39 (5), 437-439 (1989).

Citation: K. Idahor et al., "Haematological Indices, Feed and Water Intake of Grower Rabbits (Oryctolagus cuniculus) Fed Graded Levels of Sheabutter (Vitellaria paradoxa C.F. Gaertn.) Nut Meal", International Journal of Research Studies in Biosciences (IJRSB), vol. 6, no. 3, pp. 11-17, 2018. http://dx.doi.org/10.20431/ 2349-0365.0603003

Copyright: (c) 2018 Authors. This is an open-access article distributed under the terms of the Creative Commons Attribution License, which permits unrestricted use, distribution, and reproduction in any medium, provided the original author and source are credited. 